\title{
Conflito de interesses
}

Os autores do artigo submetido têm o interesse de ver o artigo publicado pela Revista Brasileira de Medicina do Esporte (RBME) por ser uma revista conhecida, pois apresentar uma responsabilidade cientifica de forma séria e ética. Conforme determinaçäo da Agência Nacional de Vigilância Sanitaria (RDC 102/ 2000) e do Conselho Federal de Medicina (Resolução $n^{\circ}$ $1.595 / 2000$ ). A pesquisa ficou sobre a responsabilidade da aluna do programa do mestrado de Bioengenharia - UNIVAP, Maria Mesquita Portela, arcando com todos os custos, não teve nenhum vinculo com patrocinios e participaçăo societária, a estrutura usada teve apoio dos colaborados, Rafael Temoteo com laboratório de analise cinemática e Leandro Pinto com academia, local onde ocorreu o treinamento. Sobe a orientação da professora Emilia. Angela e o apoio do prof Mario Lima como co-orientador.

Titulo do Artigo: Analise comparativa do padrāo do movimento entre corredores após aplicação de dois protocolos de treinamento de atrator

\section{Data 21/03/20\$8}

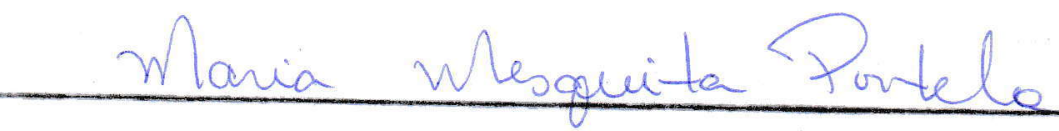

Maria M. Portela - Aluna do programa de mestrado da UNIVAP

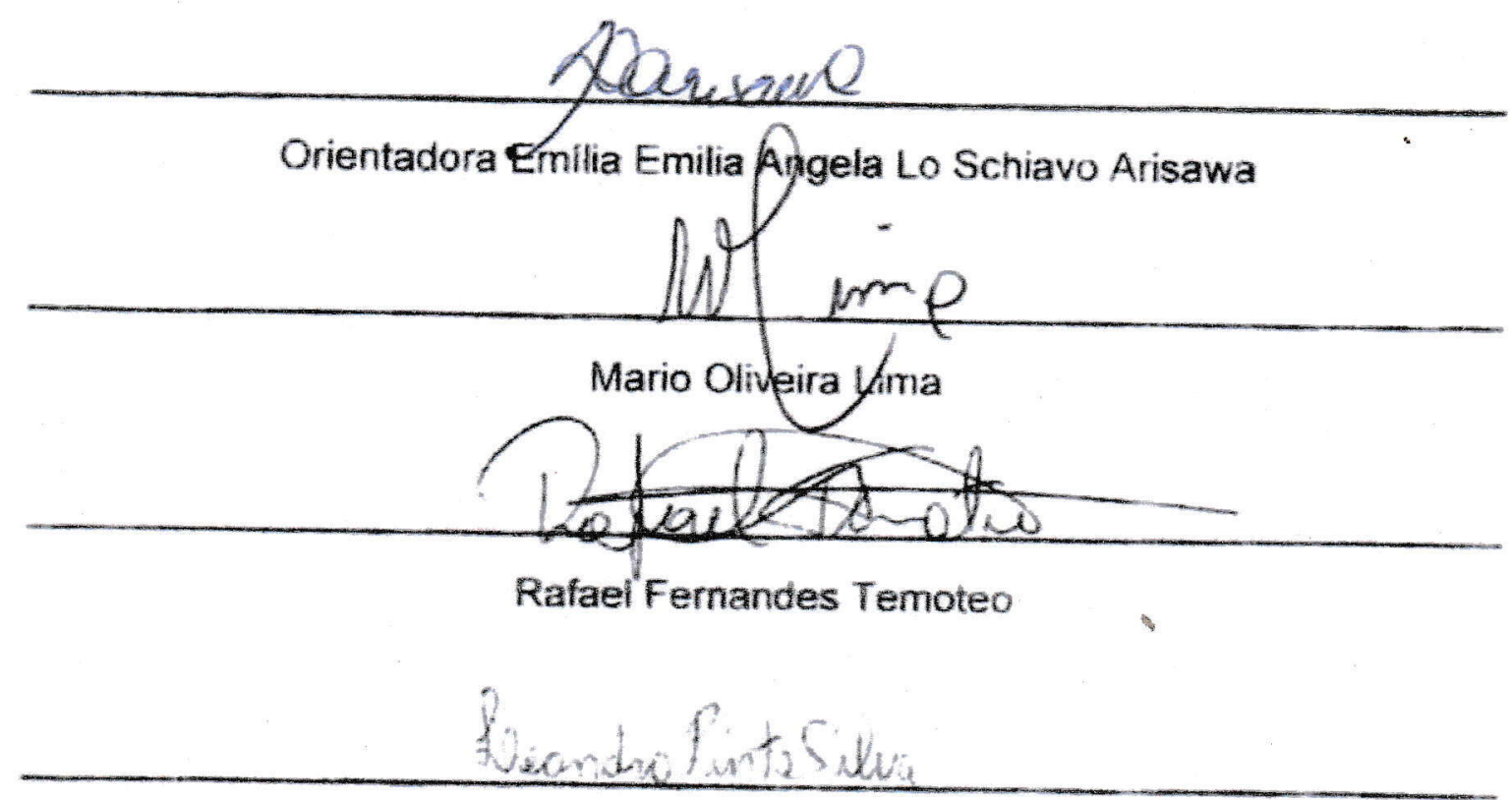

